\title{
海底砂州における微地形の発達 (2)
}

—イノサキノッガイと小与島東方海底砂州——

茂木昭夫岩 崎 博*

\section{V 小与島東方砂州}

\section{a. 音波記録に見られる海底微地形の特徴}

第17図は小与島東方砂州の東半部を $2 \mathrm{~m}$ 等深線で表わしたものである。逆くの字形のこの部分は, 起 伏のあるけわしい斜面によつて，南東側と北側を画し，なめらかな四地状をなした緩斜面によつて西側を 画している。砂州の表面は全体的には $-16 \sim 18 \mathrm{~m}$ の平坦頂であるが，所々に孤立した高まりと凹地があ る。この凹地は1925年以後の自然の埋め立てから取残された部分である。北側斜面の起伏は，下方にのび る尾根とその間の溝からなつて系統的であるが，南側斜面では斜面に必従的な数条の高まりと，これを横 断する高まりとが交錯して不規則である。第18図一第22図は, 第17図の各測線の地形断面とボトム・ソー ナの記録を，西方から順次配列したものである。

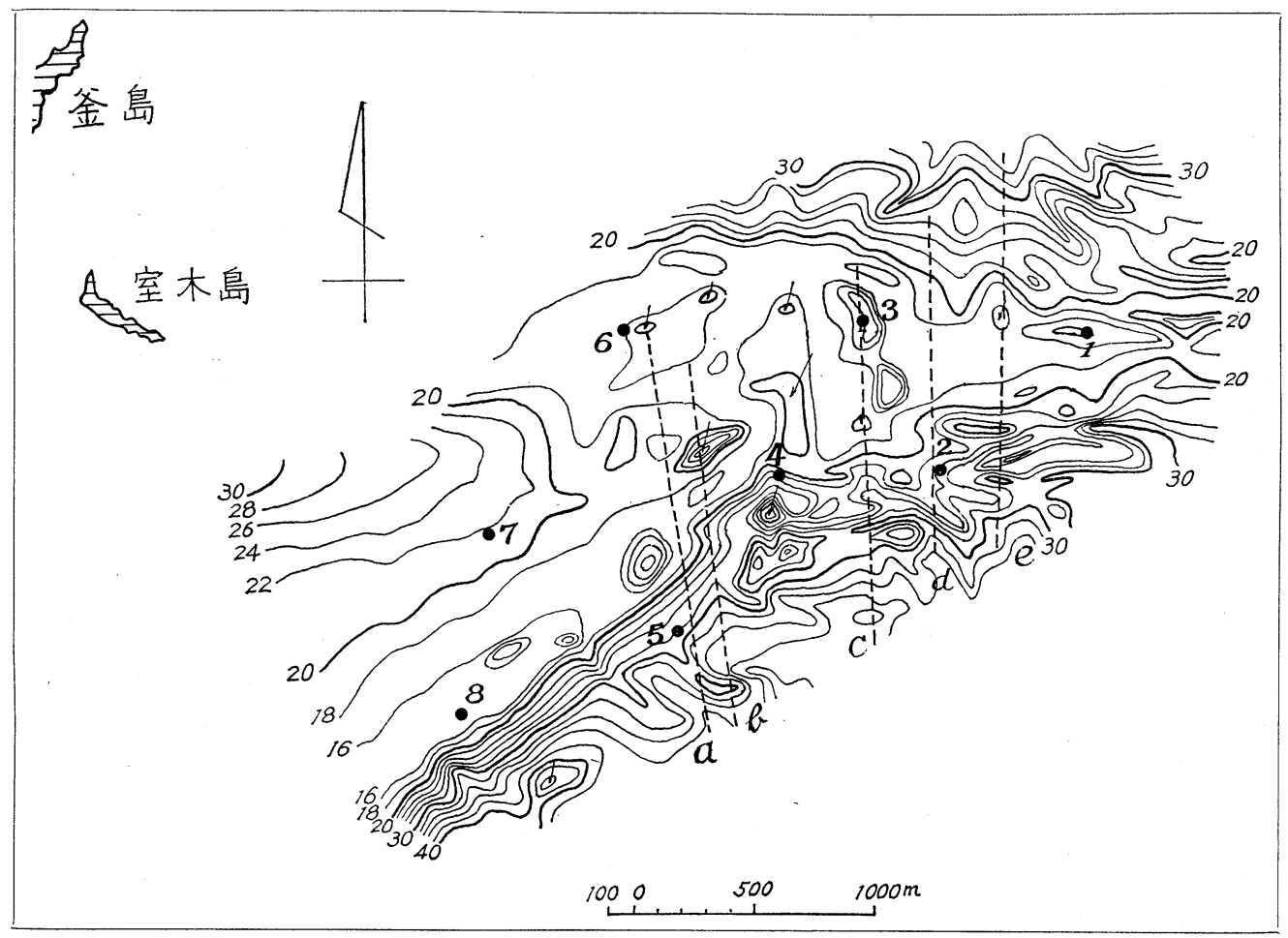

第 17 図 小与島東方砂州の海底地形

破線 $(\mathrm{a}-\mathrm{e})$ ：第18図～第22図の測線 黒丸 $(1-8)$ : 底質採取点

* 海上保安庁, 水路部 Hydrographic Department, Maritime Safety Agency 

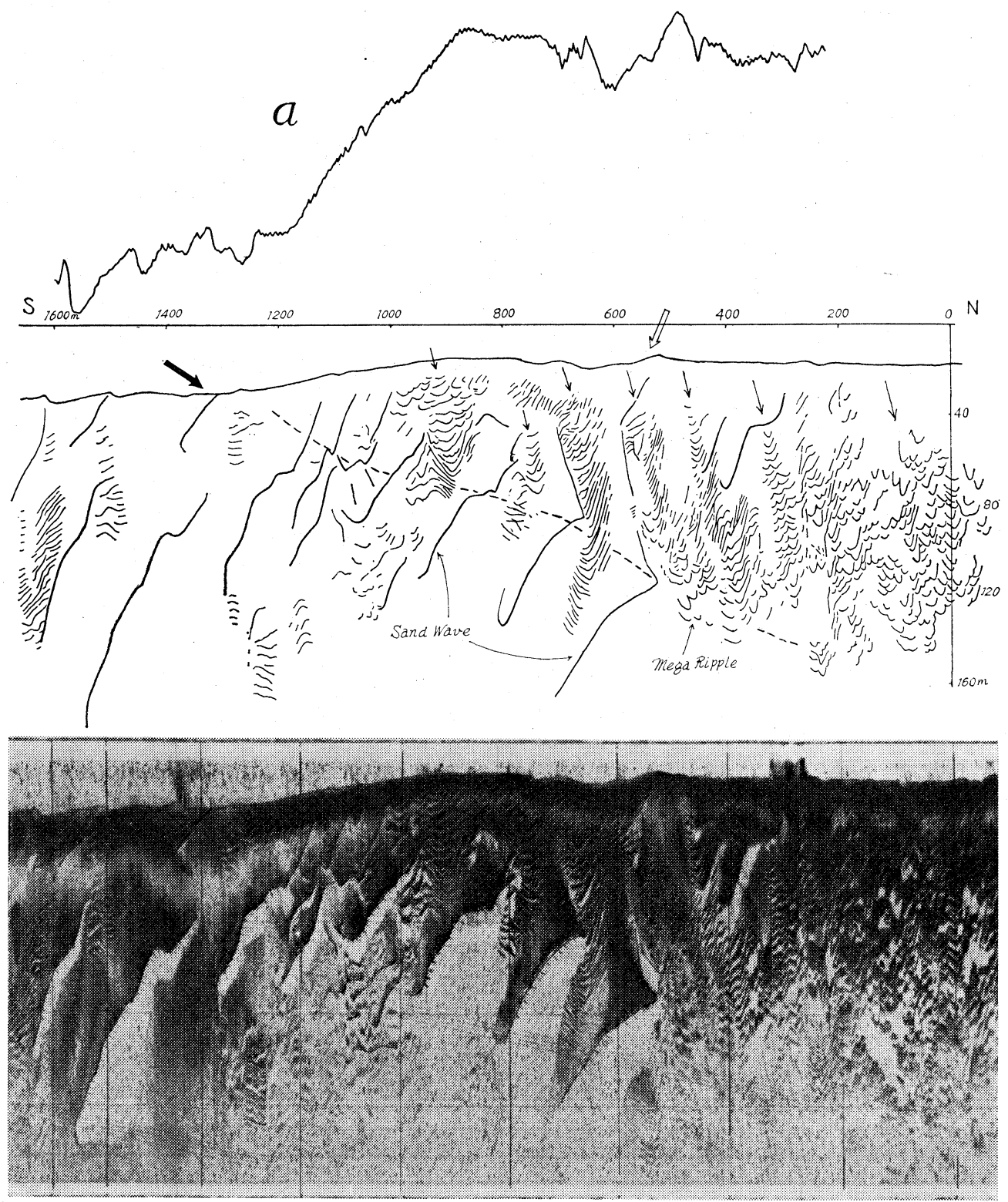

第 18 図記 録 a

上：音測断面 中：ボトム・ソーナ記録をトレースしたもの下：ボトム・ソーナ記録 黒矢印 : 主 sand wave を作つた流向 白矢印 : 従 sand wave を作つた流向 細矢印 : mega ripple を作った流向

第18図の断面を見ると, 平坦頂と南側斜面下部に大きな起伏があり，これを修飾して小さな起伏が全域 に見られる。ボトム・ソーナの記録を見ると，大きな起伏は孤立したものではなく，所々で中断されなが らもある方向に延びていて，しかも互に平行な関係を保ちながら規則的に配列している。したがつてこれ らの高まりの列は，かなり規模の大きい sand wave であることが分る。小起伏は多数の mega ripple 
茂木昭夫・岩崎 博
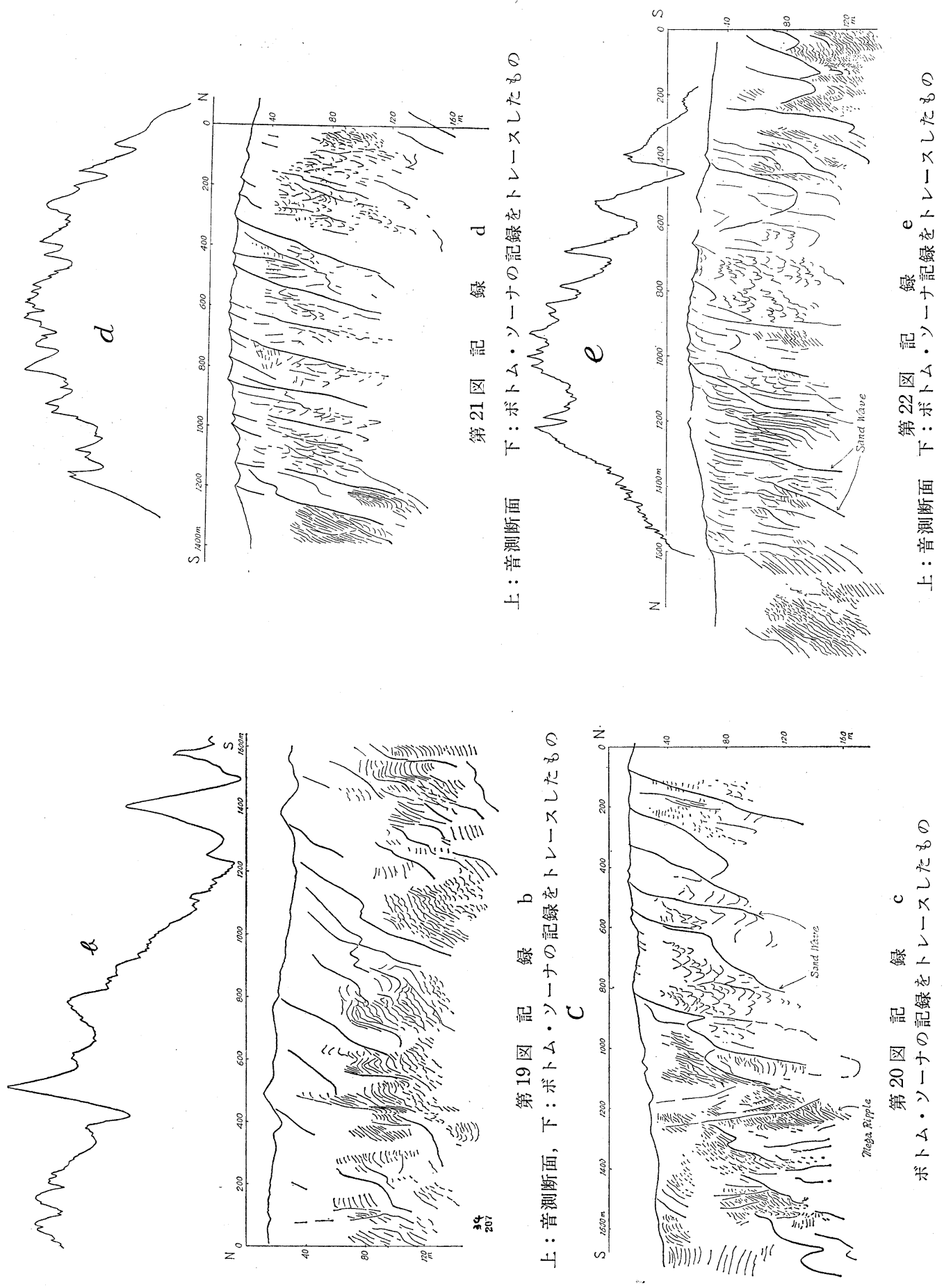
であるが，図で分る通り直線状長く連続するものはなくて短かい距離に終るが，これらが縞状に配列し て細長い帯を作つている。この mega ripple の細長い帯は, 図中に 12 13 条認められ, 注目すべきこと にこれらが sand wave を斜めに断ち切っているのである。この帯状の縞模様は, 南の方では比較的直線 的なものや彎曲したものであるが，北部に行くとウロコ型に配列したものになる。この多数の mega ripple の帯は，互に平行しており，比較的規則的な間隔をもつている。

ripple の帯は, 流れの道筋を示していると考えられるから, mega ripple を作つた流れはこの帯に沿つ た方向の流れであるに違いない。この流れの方向は sand wave を作つた流れ (sand wave に直角)の方 向に対して，約 $35^{\circ}$ の交角をなすから， sand wave を作つた流れと ripple を作つた流れとはここでは 別物であることが知られる。

もら一つ注目しなければならないことは, sand wave の峯の方向に不連続な折れ曲がりが見られること である。しかもこの段状の折れ曲がりは, よく連続して黒矢印付近から図の右下の方に向う斜めの線に沿 つた一つの峯をなしていると解釈される。この峯線は矢張り sand waveの峯を示すもので，この峯を 作つた流れの方向は，図の右上方の白矢印で示したような方向の流れであろう。この方向は既述の sand wave を作つた流れの方向に対して約 $140^{\circ}$ の交角をなす。このように見るとここには 2 方向の sand wave が交叉しており，その交叉点で更にその中間方向から来る mega rippleによつて，切断されてい ると判断されるのである。

第19図はその東側の測線で，ここには規模の大きい見事な sand wave が発達している。ボトム・ソー ナの記録は，第18図の場合と類似し， sand weve の峯は所々で mega ripple の帯によつて斜めに切断さ れている。ソーナの方向がここでは逆なので, ripple の彎曲の方向も逆になつて, 上方に凸を向ける。 sand weve の峯方向の不連続な折れ曲がりは, ここでも見られ, よく連続して一つの峯線を示している。 ここでも主 sand wave に斜めに交叉した従的な別な sand wave の存在を示しているのである。

第20図は更に東の記録である。砂州の上には平行した数条の sand wave が見られ，ここでむ途中に峯 方向の折れ曲がりが見られる。図の中央の突起部（sand wave）を境にして，その北側の砂州頂部では ripple の発達が著しく悪く, 僅かに南端付近に見られるものは, バルハン型の ripple である。一方南側 斜面には縞模様状の mega ripple の発達が著しい。斜面にはほほ sand wave に平行した二つの尾根が あり, それらの間は深い涶になつている。この尾根の斜面には, 斜面に必従なひだを示す何本かの弱い線 が見られると同時に，尾根方向に平行した megar ripple の縞模様が斜面を彩つている。

第21図は sand wave のきれいに配列した断面で, ボトム・ソーナの記録はイノサキノツガイの場合に 類似する。すなわち南側斜面に直線連続型の mega ripple, 北側斜面にはバルハン型の mega ripple が よく発達し, sand wave の発達した砂州上では発達が悪く, しかも不規則である。 sand wave の峯の折 れ曲がりは更に東の区域外で起つている。

第22図は砂州の東端で, sand wave は砂州頂部から南側斜面にかけて大規模に発達している。ここでは sand wave は, 斜面の下部に来る程大規模になっている。ボトム・ソーナで見ると，斜面の大規模な sand wave の峯は, 直線状に続いているのではなく西側で彎曲していてV字状にえぐられた形をとる。 これは等深線にも表われているように, sand wave が斜面から数条東方にのびているためであらう。山頂 の sand wave は直線状で連続がよい。 mega ripple のパターンには著しい特徴が見られる。すなわち山 頂の南側ではバルハン型の ripple が見られるのに対し, 北側ではかなり影著な直線連続型の mega ripple が見られ，その方向は大体 sand wave の峯に平行している。南側斜面下部に見られる数コのV字状 の凹地の所では, mega ripple はその背後の高まりに一面に発達しており, しかもV字形の谷と谷の境で ある峯 (sand wave) の所に, 集中するように配列している。これは斜面から峯に沿う砂の移動の存在を 示しているのであろう。

b. 小与島東方砂州における微地形分布のパターン 


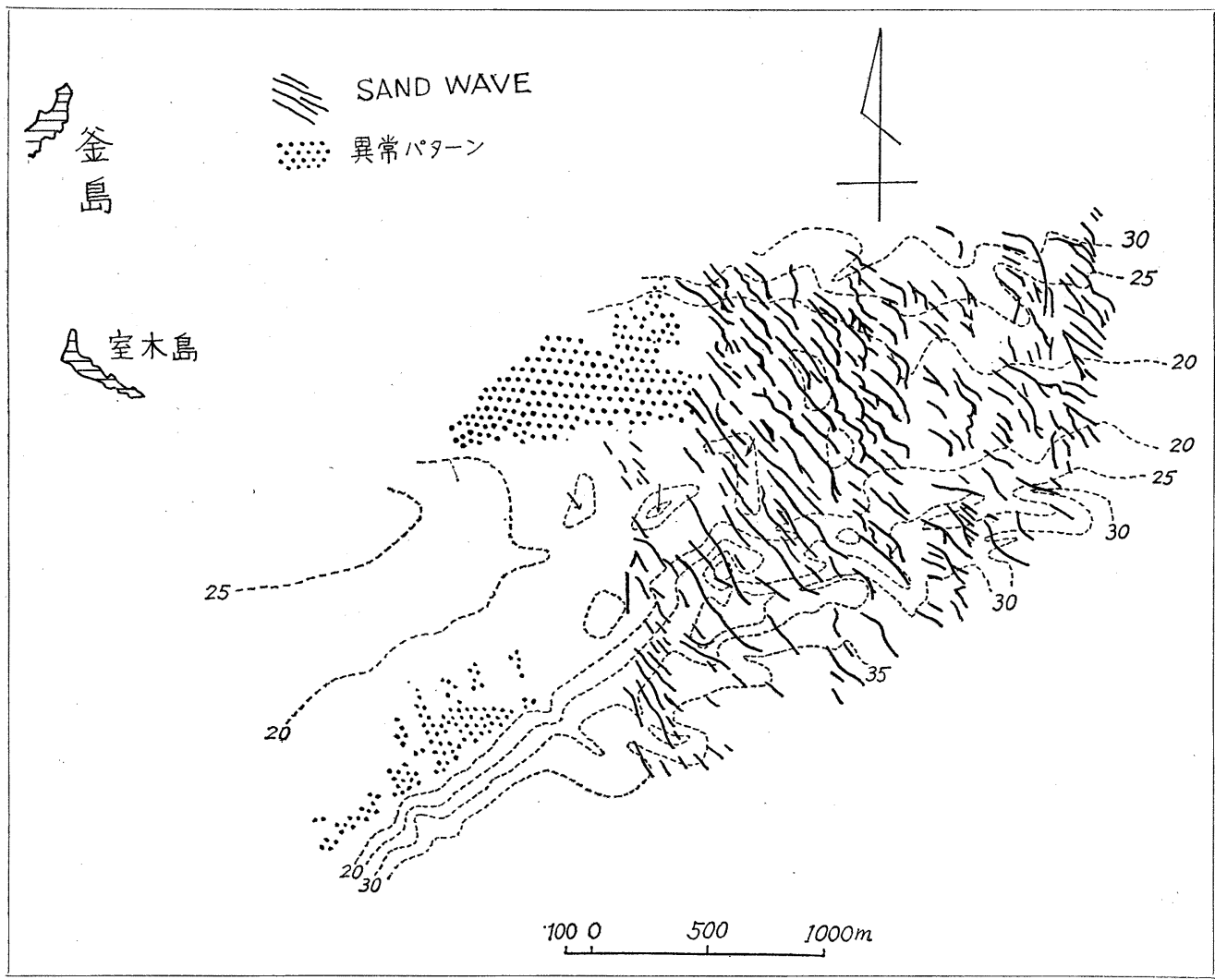

第 23 図 小与島東方砂州に抒ける sand wave の分布

小与島東方砂州についてもイノサキノツガイと同様な方法により，第23図および第25図を作成した。 (1) sand wave

第23図に見られる通り，小与島東方砂州においても比較的直線状の連続のよい sand wave が卓越する が，イノサキノツガイの場合と異なる点は，連続性が悪くてしばしば中断され，しかも屈曲したり分岐し たりしている点である。この sand wave の型を一応直線連続型から区別して, 屈曲型と名付ける。

sand wave の一般的な方向性は顕著で，NW一SE の方向をとる。この方向は小与島からのびる南側砂 州の延び方向に対して，直角な方向である。ところでこの砂州は，その南側の中央水道を往復する約 3 ノ ットの潮流によつて，流れの方向に小与島からのびてきたものであることは，最近の地形変化からも明ら かであるから，この潮流方向にほぼ直角に配列している sand wave は，砂州の南側の中央水道を流れる 潮流によつて，形成されたものであることは容易に理解できる。恐らく与島・三ツ子島間を通つて東に向 う流れ(東流)が，砂州の南側斜面に沿つて流れた後，砂州の合流部で斜面が東に向きをかえるあたりか ら，砂州上に乗り上げ砂州の先端部を斜めに横断して，砂州の北東側の 深みに 抜けるのであろう。 sand wave は, 砂州がこのような潮流に洗われる部分に 発達しているといら事ができる。そしてまた sand wave の発達している所は，イノサキノツガイの場合と同じように，現在もなお活発に砂州が成長してい る部分にも当る。

先に述べたように，ここの sand wave は屈曲型で，延長は短かく平面形はかなり不規則である。第18 図のボトム・ソーナの記録で見られたように， sand wave の鉎の折れ曲がり部分（屈曲部）はよく連続 
しこれれをつらねた線は，方向の異な 別つたの sand wave の存在を暗示す る。第 24 図は sand waveの峯線をそ の方向によつて 2 種に区別して示したも のである。顕著な NW-SE 方向の峯 線は, 前述の sand wave で, 南側中央 水道から流れこむ潮流に帰因したもので ある。これに対して極めて短小な折れ曲 がりの部分をつらねた線は, よく連続し て一つの方向線を示しており，しかもこ のような線が数条，等間隔に平行に配列 していて，1つの系統的な高まりの配列 を示しているのである。その方向はNNE

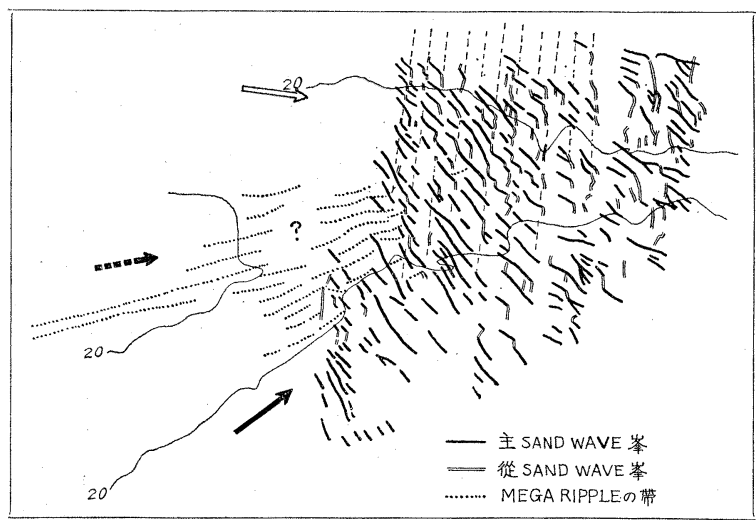

第 24 図 小与島東方砂州における方向別に見た sand wave の举と mega ripple の帯 -SSW で，興味あることに，釜島から のびる砂州方向にほぼ直角な関係にある。このことは，この断片的な高まりの列は，下津井瀬戸を通つて 南東流し，釜島から南東にのびる砂州の部分を作つた潮流に関連して作られた別の sand wave 系ではな いかと推定されるのである。すなわち二つの砂州の合流部に顕著に発達している屈曲型の sand wave は, これらの砂州を作つた 2 方向の潮流が，それぞれの sand wave を発達させたので， 2 方向の sand wave がこの部分で重なり，不規則なパターンをもつた屈曲型の sand wave を現わしたものと考えられる。 sand wave には NW一SE の方向性が遥かに優勢である所から見て，現在中央水道を 流れる潮流の影響 が，とくに強いことも納得される。

合流部から西の南北両砂州の部分に，ボトム・ソーナの記録に異常なパターンを示す地域がある。斑点 状の不規則な記録で，今のところその正体は分つていない。地質から見て岩盤は露出しておらず中ノ瀬層 であり，実際 2 力所の底質調査の結果では，淘汰の悪い礫・細砂である。したがつて礫層が特殊な条件下 で，このようなパターンを示す地形を作つているのであろう。それではその条件とは何であるらか。第 1 図で見ればこの異常記録が現れる地点は，南砂州では中央水道への張り出し部分，北砂州でも矢張り南へ の張り出し部分に当る。南砂州では明らかに急斜面をはい上つた縁の部分に顕著であり，多分潮流がこれ らの張り出しに当つて乗り上げた時の乱れが，磞層に作用して作つたものではあるまいか。砂の場合我々 はそこにバルハン型(斑点不連続型)を見たが，礫の所ではこれに類似しながらも，そのようなハツキリし た形態をとれない事によるのであろらか32。

(2) mega ripple

第25図は mega ripple を直線連続型，屈曲型，斑点不連続型に分けて，その分布を示したものである。 この図で見られるように，砂州の合流部の西半に広く直線連続型の ripple が分布し，その東の砂州先端 部には，斑点不連続型の ripple が分布している事が明滕である。

砂州先端部には ripple の全く発達していない所も見られ, 一般に ripple の発達は悪く地形は 複雑で ある。この分布状況は，先に見た sand wave の分布と照合して見れば，大局的に sand wave の発達し ていない砂州合流部西半に, 直線連続型の mega ripple の顕著な発達が見られ, sand wave の発達して いる合流部東半(先端部)では, ripple の発達が悪く, 発達しているものは斑点不連続型のものであるとい う，一般的な傾向が存在することを知ることができる。この傾向は，先にイノサキノツガイで見たもの

3）礫はこの 2 カ所にのみ分布しているわけではなく，調查域の西部に広く分布しているのであつて， ある所では mega rippleなどを形成している。したがつてこのようなパターは，礫が特殊な条件 の場合にのみ生ずると考えられる。 


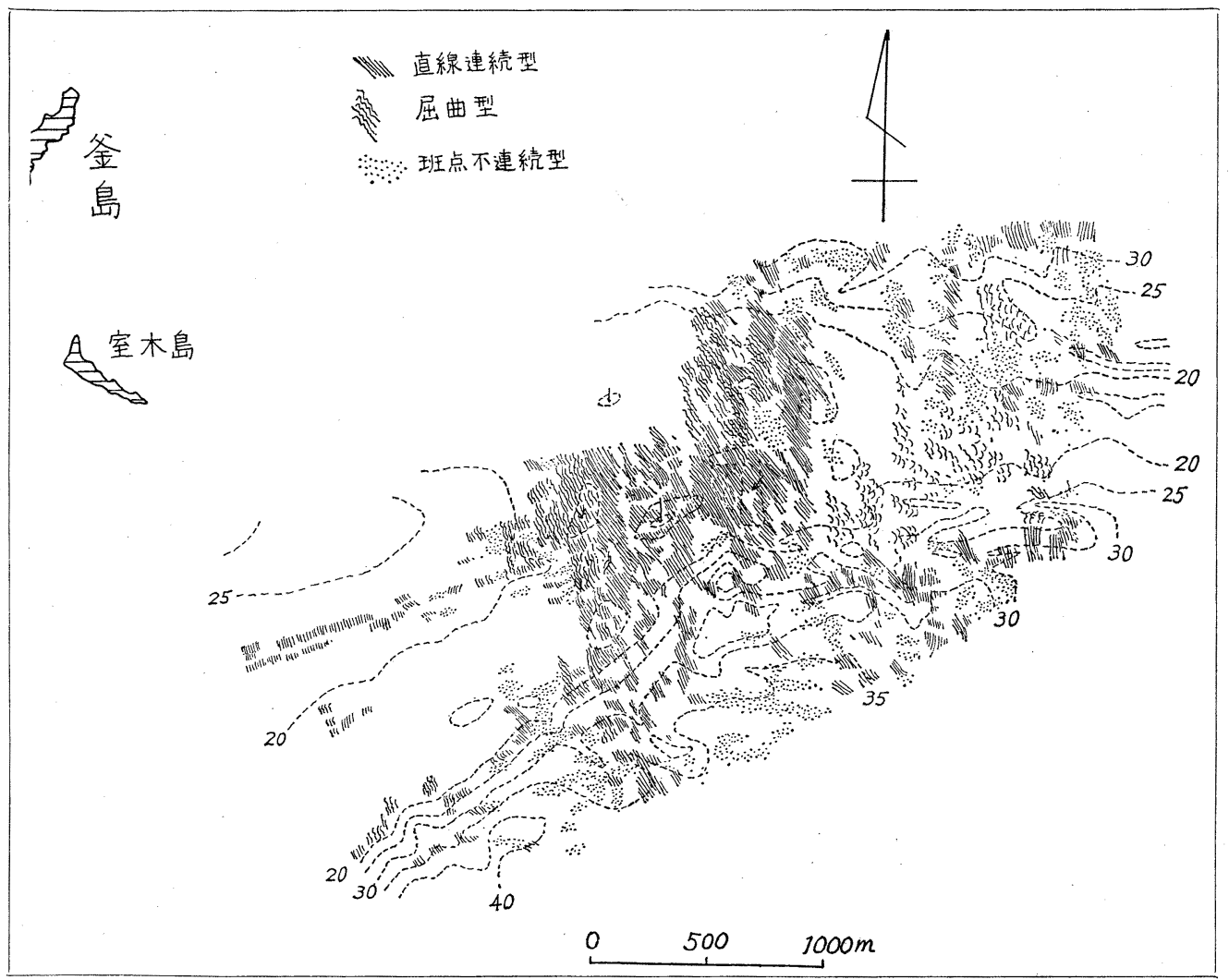

第 25 図 小与島東方砂州に㧍ける mega ripple の分布

と，大変類似したものであることも知られよう。イノサキノツガイの場合と異なる点は, sand wave と 直線連続型の mega ripple の重複部分が，かなり大きいという事である。第 18 図で NW-SE 方向の sand wave が, mega ripple の帯によつて切断されている例を見た。これは sand wave の峯をつき破つ て，この帯に沿つて流入してくる流れが存在することを示し，この流れによつて起された漂砂が，その流 路に mega ripple の帯を作つたと解釈される。ripple の峯はこの流れに直角に縞状に配列しているが, 時に先端部などで流れの方向に向つて concave な形 (三日月形)を示し，極端な場所では，同じ方向の三 日月形がウロコ状に重なりあつたバルハン型の ripple を形成する。この型の場合でも，その配列状態に ripple の帯が認められるのである。この ripple の帯の方向は, NW-SE 方向の sand wave を作つた 潮流方向に対して, 約 $35^{\circ}$ の交角で恋わつており, その方向は逆くの字形のこの砂州の西側彎入部の方 向に一致するのである。

第24図にこのような ripple の帯の認められるものを摘出して示したが，西側彎入部の緩やかな斜面の 溝に沿つて, 見事な ripple の道が形成されている事が分ろう。これは砂州の上に上ると同方向の多数の ripple の帯となって平坦面を彩つているが，NW一SE 方向の sand wave 地域に達すると， sand wave の锋をつき破って中に入りこみ, sand wave と mega ripple の広い重複地帯を形成している。この ripple の縞状の帯の示す流れは，釜島と与島の間の島々を通り抜けて，東西方向に流れる約 2.8 ノットの潮 流に当り，この東流が彎入したゆるやがな面を，乱されることなく砂州にはい上るために，砂州の上に見 事な縞状の mega ripple を形成したと考えられる。 


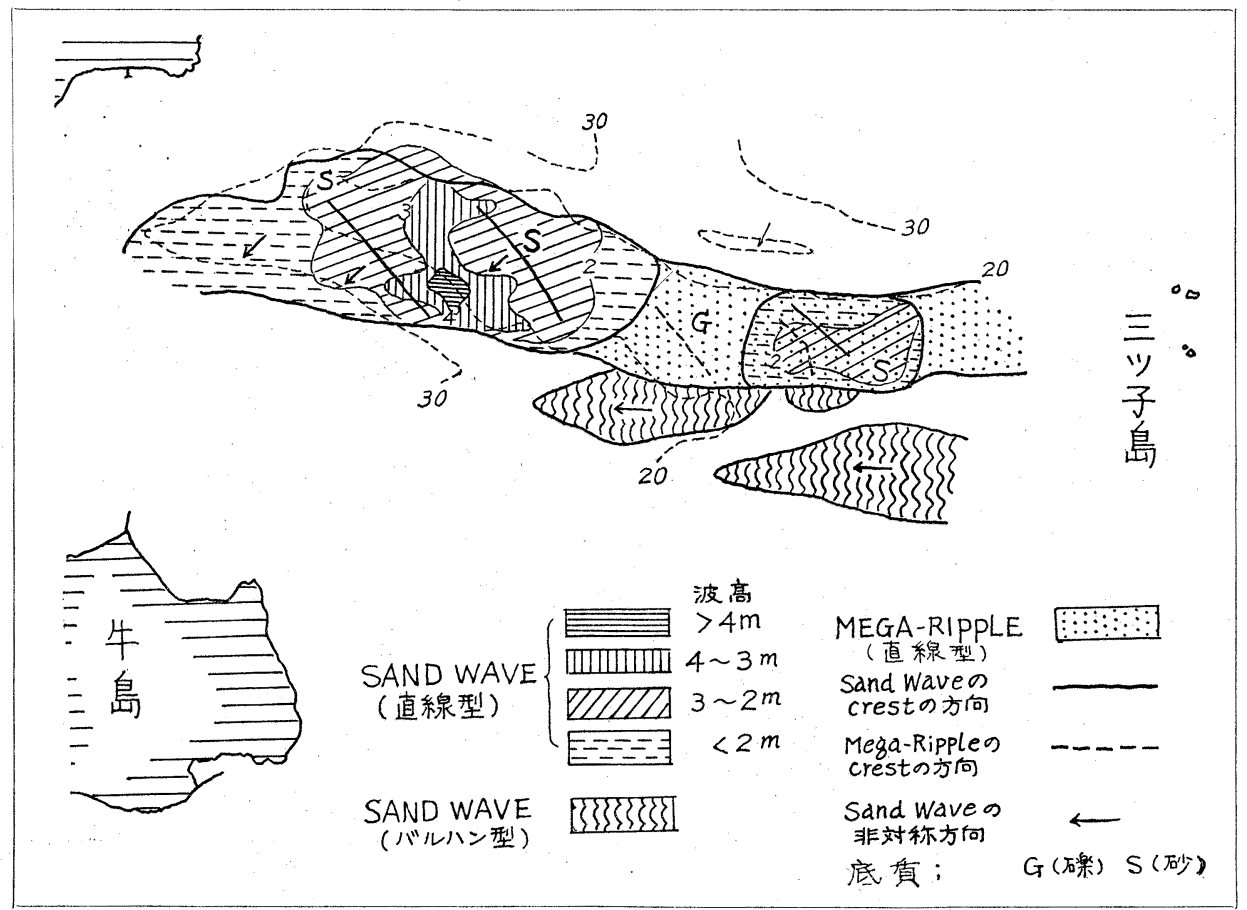

第 26 図イノサキノツガイの微地形分類図

先に述べたように砂州の合流部では, NW-SE 方向の sand wave と NNE-SSW 方向の sand wave とが交文して，格子状の折れ曲がりを作つた。ここに西方から別の流れが流入すると，東方に彎入した折 れ曲がり部分に集中するので，この部分をつき破ることになる。第18図のボトム・ソーナの記録は，この 現象を見事に表わしている。

(3) 海底微地形と底質との関係

この区域の 8 地点から底質を採取したが, 東半および南側の 4 地点が砂質で, 西半の 4 地点が磞質であ るという著しい特徵を示している(第17図採取地点参照)。

まず東部の No. 1 と No. 2 は, 少量の粗砂を含むが, 貝殼破片も非常に少なく, 淘汰のよい中砂で ある。No. 3 ではやや粗くなつて粗砂が多くなり, 若干の細磂も含む。淘汰は悪い。No. 5 は No. 2 と 同じように南側斜面にあるが，底質も非常によく類似し，淘汰のよい中砂である。

No. 4 は 1 0.5cm 大の淘汰のよい角ばつた磉で貝破片もかなり含んでいる。採取地点は sand wave の峯の間の谷間であろうと思われる。

No. 6 は No. 4 よりも更に粗粒な亜角礫であるが，粒径は 1 1.5 cm が普通で $2 \mathrm{~cm}$ に達するものも ある。少量の粗砂とかなり大きな貝殸を含む。No. 7 は粗砂をかなり含んだ数 $\mathrm{mm}$ 径の細碑で, 少量の 貝款破片を含む。No. 8 は No. 7 と No. 4 の中間位の粗さの細礫・礫・粗砂であるが, 淘汰が悪く, $3 \mathrm{~cm}$ に達する碟を含み, 少量の貝款破片を含む。

この底質分布の全体的な傾向は，海底微地形の分布パターンと極めてょく一致していることが知られ る。すなわち東半の砂質の海底は, sand wave や斑点不連続型の mega ripple の分布域であり, 西半の 砅質の海底は, 直線連続型の mega ripple や異常パターンの分布域とよく対応している。更にくわしく 見れば，粒径の最も大きい磷の所では異常パターンを作り，これよりも小さい細磁の所では，淘汰の悪い 


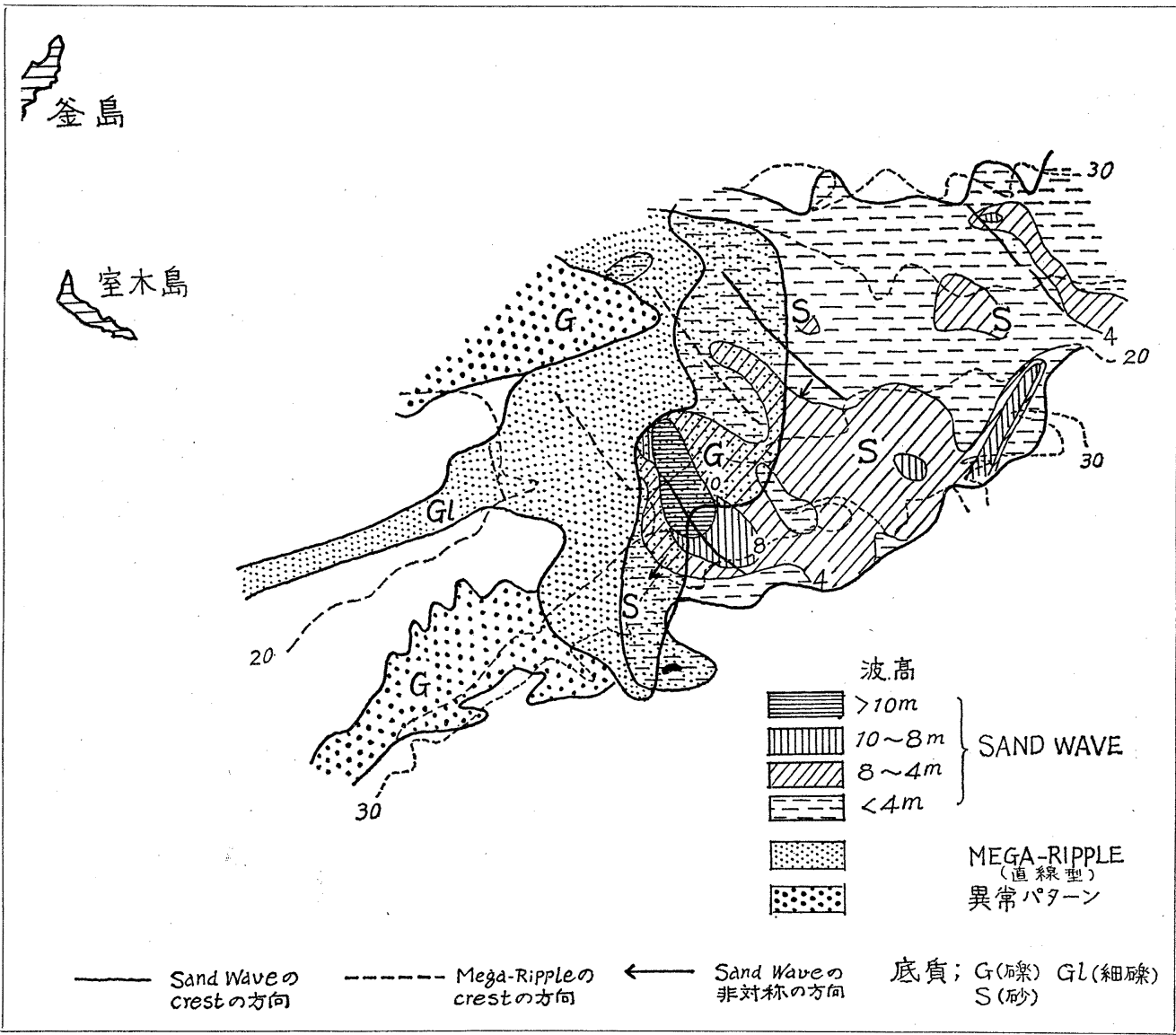

第 27 図 小与島東方砂州の微地形分類図

所 (No. 8) で異常パターンを, 淘汰のよい所で直線連続型の mega ripple を作り, 粗砂・中砂の所では sand wave と斑点不連続型の mega ripple が現れるが，とくに後者は中砂の卓越する砂州先端部で顕著 である。特異なのは sand wave の発達の最も著しい中央部で, No. 3 と No. 5 は少量の細磉を含むが 中砂・粗砂であるのに対し，No. 4 は細磁・磁であることである。これらの地域は sand wave と直線連 続型の mega ripple とが交錯している所であるから，峯の部分の砂質と谷の部分の磞質とが，それぞれ 現れたものではなかららか。

このような海底微地形と底質との密接な関連は，イノサキノツガイで見られた関係と大変よく類似した ものであることに，注意する必要がある。

\section{VI sand wave と mega ripple との関連}

以上の記載に見られたように，イノサキノツガイと小与島東方の海底砂州に，共通して明らかに独立し た sand wave の領域と mega ripple（直線連続型）の領域とが，存在することが知られた。

そして両区域は常に接していて，その境界はかなり重複している。海底砂州を形成している漂砂の方向 から見ると, mega ripple の領域が上流側にあり, sand wave の領域が下流側にある。この分布様式から すると，潮流によつて起された漂砂は，まず mega ripple を形成し，次いでその下流側に大規模な sand 
wave を形成しているように見受けられる。

一方このような画然とした微地形分布のパターンは，底質の分布との間に見事な一致を示した。すなわ ち mega ripple は明らかに細砂の領域に形成され, sand wave は粗砂, 中砂の領域に形成されていると いうことである。この事赛は粗粒の大きい硌や細礫では，規模の大きい sand wave は作らないで mega ripple を作るに止まるが，それよりも粒径の小さい粗砂・中砂では，大規模な sand wave を作るのでは ないかといら考えに導く。これまでも sand wave は, 砂の範囲内で粒径の平方根に比例しながら増大す る (KING，1959） が，礫の分布域に至ると突如として消失するといら事実が知られている（茂木・加藤, 1962)。一部の碟堆で sand wave の存在が知られているが，そこでは規模が小さく，分類からすると mega ripple の範ち泫らに入る(陽，1965，茂木，1973)。

したがって定量的な関係は未だ得られていないが, 多分粒径の増大と共にその規模を増した sand wave は，粗砂・細磁付近を頂点にして，急激にその規模を減少し， mega ripple に転化するのではなかろらか と推定される。

この 2 つの現象を組合わせて考えると，海底砂州の上で潮流によつて行われている漂砂は，長い間に底 質を粒径によつてふるい分け，細粒部分を洗い出して，砂州の先端部に運ぶため，上流側に粗粒底質が残 り，下流側(砂州先端部) 亿細粒底質が集積することになる。粗粒底質が細砅以上であると，そこには mega ripple の領域が形成されるが，これに接する粗・中砂域には突如として規模の大きい sand wave が 現れるという事になる。粗粒域(礫質)と細粒域(砂質)とがその境で交錯すると, 波長の長い sand wave の中に波長の短かい多数の mega ripple が介在することになろう。

その関係を実際の例で見ると, mega ripple は sand waveの峯と峯の間の谷部に主として存在し， ripple の峯の方向は sand wave の峯方向に対してほぼ平行な場合もあるが，しばしば斜交したり，時に は直交し, sand wave の谷方向に彎曲している場合も見られる。小与島東方の海底砂州に見られたよう に, この ripple の帯が sand wave の峯を斜めに切断している場合も存在する。

このような事実は碩質が低い谷部を作つており，砂質が高い峯部を作つていると判断され，現にここで 底質のふるい分けが行われている事を示しているのではあるまいか。 sand wave 内での底質分布につい ては，この場合と逆の現象も知られているが，備讃瀬戸東部で調查した本座ら (1968) は，谷部の粗粒，峑 部の細粒を報告していて，この関倸を支持している。

しかし sand wave と mega ripple (直線連続型)の領域の形成が，一義的に底質粒径にのみ依存して いるのであろらか。両者の交錯した地域では, sand wave の峯方向に対して斜交した mega ripple や, 時に sand wave を斜めから切断した mega ripple の帯が存在していて, 明らかに sand wave を作つ た流れとは異なつた方向の流れが， mega ripple を形成した事を暗示している。小与島東方砂州の場合， その方向は ripple の帯(道)として逆くの字型のこの砂州の西側彎入部緩斜面まで追跡された (第24図)。 したがつてここではこの mega ripple のパターンを作つたのは, sand wave を作つた南西からの流れで はなくて，これと約 $35^{\circ}$ の交角をなす東西流であることは先に述べた所である。

この流れは彎入部の深みに沿つて緩やかな斜面を上つてくるであろらから，乱れの少ない斉一な流れで あろらと思われる。 sand wave を作つた急斜面を乗り上げる乱れの多い流れとは異なるであろら。この ような流れの性質もまた，一方では整然とした縞状の mega ripple を形成し，他方では斑点不連続型の mega ripple に彩られた sand wave の地域を形成するのに関与しているのではなかららか。イノサキノ ツガイの場合でも mega ripple の発達している頸部は，与島・三ツ子島間を西流する流れに対して緩や かに彎入しているが，その西の sand wave 地域では流れの方向に対し張り出している。南側斜面の谷状 の深みに沿つて短小な ripple の带が見られることも，同様な現象であろう。イノサキノツガイで潮流の 乱れを測定した小笹 (1975) は， sand wave の発生の原因を，潮流が斜面を乗り越える際に生ずる乱れに 求めている。 


\section{VII 海底砂州における微地形発達の機構}

備讃瀬戸西部におけるイノサキノツガイと小与島東方砂州について, ボトム・ソーナによつて 微地形を 調查した結果，海底砂州上には規模の大きい sand wave と，規模の小さい mega ripple とが広く発達 していることが分つた。これらの微地形の分布状況と砂州地形との関連から, 海底砂州およびその上の微 地形の発達に関して, 次のような新しい知見が得られた。

(1) 砂州は島陰に作られ水道を抜ける強流に沿つて細長くのびる。砂州を作つた漂砂は, 島から先端部 に向うもので, イノサキノッガイでも小与島東方砂州でも, 最近 50 年間に先端部が著しくのびて, 現に成 長過程にあることを示している。

(2) 東流と西流とが，横合から入りこむ開水路などの影響を受けて，別流路をとると，イノサキノツガ イのような特異な方向をもつた砂州が形成される。2 カ所から流れこんだ流向の異なる潮流が合流する と，小与島東方砂州のようにそれぞれの砂州が合成してくの字形に折れ曲つた砂州を作る。

(3) sand wave は砂州の先端部付近に顕著に発達する。先端部付近は潮流が砂州の上にはい上つて洗う 所であり，現在漂砂が活発で成長している部分に当る。

(4) sand wave の方向は, 砂州を形成している潮流の方向に対して, 直角に配列する。そして sand wave の配列方向は, 長い間に砂州の形態を規定する。たとえばイノサキノツガイの sand wave の緩や かな彎曲やその方向の変化は, 砂州の彎曲した地形を作るのに影響したし, 小与島東方砂州の 2 方向の sand wave の交叉による折れ曲つた形の sand wave は, 逆くの字形の砂州を形成するのに貢献したであ ろう。

(5) sand wave には通常斑点不連続型の mega ripple が伴う。この型の ripple は, 潮流が張り出し た斜面を越える所に現れ，著しい乱れの発生に原因すると思われる。したがつて sand wave は潮流が斜 面を越える時に生ずる乱れに帰因して生ずるものと思われる。

(6) sand wave は直線連続型, 屈曲型, バルハン型の 3 種に分類される。直線連続型 (イノサキノッガ 1）は，潮流がほぼ一方向からくるために生ずるものであり，屈曲型(小与島東方砂州) は，2 方向以上の 潮流によりそれぞれ作られた sand wave が，合成（交叉）されたものである。バルハン型は乱れが大き く, 多方向の流れによつて形成されたものと推定される。

(7) 直線連続型(縞状)の mega ripple は, 通常, sand wave と分布領域を異にする。この型の ripple は, 流れが凹地に沿う所や彎入部に入りこむ所に現れ, 比較的乱れの少ない斉一な流れによつて形成され る。このような流れが入りこむ所では, mega ripple の縞状の帯は, しばしば sand wave の峯を切つて その中に侵入することがある。

(8) sand wave と mega ripple（直線連続型）の領域は, 底質の粒径にとくに著しく支配される。粗 砂・中砂の所には sand wave(斑点不連続型の mega ripple を伴う)が発達するが, 細砅の所では直線連 続型の mega ripple が形成され, 磁の所では異常パターンが形成される。

(9) 海底砂州では先端部に向う漂砂が行われており，これにより上流側では細粒部分が洗われて粗粒と なるため, 礫質の所に直線連続型の mega ripple が形成されるが，これに接する先端部では細粒部分が 集積して，そこに大規模な sand wave が形成される。両者の境では現にふるい分け作用が行われている ため, 大規模な sand wave と小規模な mega ripple が共存する。

\section{VIII あとがき}

ボトム・ソーナによつて, 備讃瀬戸西部にあるイノサキノツガイと小与島東方砂州の 微地形分布を明ら かにし, その事実に基づいて海底砂州と微地形の発達に関する若干の新知見を得ることができた。海底砂 州にも異なつた性格をもつものもある筈であるから，このような調查を更に他の海底砂州に 及ぼすことに 
よつて，一層潮流による海底地形の発達機構の解明に近づくことができるであろう。

本稿を昭和 51 年 3 月をもつて停年退官される，東北大学能登志雄教授に献呈します。この調查に参加さ れた三洋水路測量 K.K. の西岡博司氏外の班員に感謝する。

\section{文献}

Belderson, R. H., Kenyon, N. H., Stride, A. H. ANd A. R. Stubbs (1972) : Songraphs of the seafloor, Elsevier Publ. Co. 180p.

中条純輔(1967)：ボトム・ソーナーの超音波の散乱と記録について。地質調月報 18，5，14-32.

中条純輔 (1968) : 海底の探查と電子技術. 電子通信学会誌 51, 5, 599-605.

星野通平・岩淵義郎 (1963) : 備讃瀬戸の生いたらに関する $2 \cdot 3$ の問題——鍋島水道を例にして一。 地質雑 69, 810, 147-156.

本座栄一・奈須紀幸 (1968)：備讃瀬戸に抢ける sand wave の移動形態. 海洋地質 4, 1，16-26.

本座栄一・加賀美英雄・奈須紀幸 (1970)：備讃瀬戸の海底地質．海洋地質 6, 1，12-33.

海上保安庁水路部 : 備讃瀬戸西部潮流図.

KING, C. A. M. (1959) : Beaches and Coasts. Edward Arnold, 403p.

桑代 勲(1959)：瀬戸内海の海底地形。地理評，32，1，24-34.

茂木昭夫 (1973) : sand wave の $2 \cdot 3$ の特性. 東北地理 $25,3,165$.

茂木昭夫・加藤俊雄 (1962) : 備讃瀬戸東部の sand wave について. 海洋地質 1, 1, 2-12.

小笹博昭(1975)：サンド・ウェーブの発生環境条件汇関する解析調查. (印刷中)

杉浦邦朗 (1973)：サンド・ウェーブ(砂浪)地形について. 海洋科学 5，12，42-46.

陽 清 (1965) : 関阴海峡の sand wave について. 水路要報 79, 7-16.

(1975年 2 月 4 日受理) 